THE GLOBALIZATION OF FOREIGN INVESTMENT IN AFRICA

The Role of Europe, China, and India 


\title{
THE GLOBALIZATION OF FOREIGN INVESTMENT IN AFRICA
}

\author{
The Role of Europe, \\ China, and India
}

\author{
BY \\ Adams Bodomo \\ University of Vienna, Vienna, Austria
}

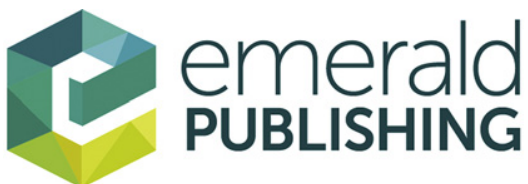

United Kingdom - North America - Japan India - Malaysia - China 
Emerald Publishing Limited

Howard House, Wagon Lane, Bingley BD16 1WA, UK

First edition 2017

Copyright (C) 2017 Emerald Publishing Limited

Reprints and permissions service

Contact: permissions@emeraldinsight.com

No part of this book may be reproduced, stored in a retrieval system, transmitted in any form or by any means electronic, mechanical, photocopying, recording or otherwise without either the prior written permission of the publisher or a licence permitting restricted copying issued in the UK by The Copyright Licensing Agency and in the USA by The Copyright Clearance Center. Any opinions expressed in the chapters are those of the authors. Whilst Emerald makes every effort to ensure the quality and accuracy of its content, Emerald makes no representation implied or otherwise, as to the chapters' suitability and application and disclaims any warranties, express or implied, to their use.

British Library Cataloguing in Publication Data

A catalogue record for this book is available from the British Library

ISBN: 978-1-78743-358-8 (Print)

ISBN: 978-1-78743-357-1 (Online)

ISBN: 978-1-78743-455-4 (Epub)

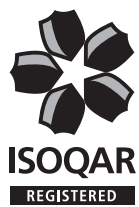

Certificate Number 1985

ISO 14001
ISOQAR certified Management System, awarded to Emerald for adherence to Environmental standard ISO 14001:2004.

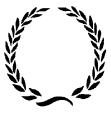

INVESTOR IN PEOPLE 


\section{CONTENTS}

Acknowledgements

Foreword

1. Introduction: Globalizing Foreign Investment in Africa

1.1. Socio-Economic Theories

1.2. Socio-Political Theories

1.3. Socio-Cultural Theories

2. Conceptual Groundings: The Role of FDI in National Development

2.1. Introduction

2.2. FDI: Definitions and Conceptualizations

2.3. Arguments for FDI

2.4. Arguments against FDI

2.5. Conclusion: We Need FDI

3. Looking Back into History: European Investment in Africa

3.1. Introduction

3.2. Historical Overview

3.3. Essential Features and Constraints of European Investment in Africa

3.3.1. European Socio-Economic

Conditionalities

3.3.2. The Export of Global SocioPolitical Values 
3.3.3. European Views of Africa as a Humanitarian Burden 26

3.4. How Europe Can Re-Invent Itself in Africa 27 3.4.1. Let Politics Be Politics and Investment Be Investment

3.4.2. Trade and Investment, Not Aid 29

3.4.3. The Role of the African Diaspora 29

3.5. Conclusion

30

4. In Comes the Dragon: Chinese Investment in Africa

4.1. Introduction

4.2. Features of Chinese Investment in Africa:

A Paradigm Shift

4.2.1. Conditions of Engagement But No Conditionalities

4.2.2. Equality of Partnerships

37

4.2.3. Aid Versus Investment

37

4.3. Global Growth Companies

39

4.4. China's Success in Africa: Lessons for

43

4.5. Conclusion

44

5. The Elephant Stands Up to the Dragon: India's 21 st Century Investment Initiatives as a Reaction to China in Africa

5.1. Introduction

49

5.2. History of Indian Investment Presence in Africa

5.3. Indian Awakening in Africa: Evaluating Investment Initiatives

5.4. How Unique Does India Want to Be? 61

5.5. Conclusion

6. Newer Alternative Foreign Investment

Sources in the 21 st Century

6.1. Introduction 
6.2. The GEEP or the 'BRICS'

6.2.1. Brazil 68

6.2.2. Russia 69

6.3. Rising Asian Stars: Turkey and Indonesia 71

6.3.1. Turkey 71

6.3.2. Indonesia 72

6.3.3. Other Asian Players 73

6.4. Central and South America: Cuba and Beyond 74

6.5. Conclusion 74

7. The Lion Must Roar: Towards an

Africa-Driven Investment Policy in an

Era of Globalization

77

7.1. Introduction: Critiquing Africa-China

Relations

78

7.2. The Fallacy of the 'Win-Win-Win'

Hypothesis for Africa, China and the West 79

7.2.1. WWW-Hypothesis

80

7.2.2. Four Formal Arguments against

an Africa-China-West

Trilateralism Hypothesis

7.3. The WWW-Hypothesis versus an

Alternative AWA-Hypothesis

7.3.1. Africa-Driven Win-for-All

(AWA)-Hypothesis

86

7.4. The Role of the African Union (AU)

87

7.5. Conclusion

7.5.1. Africa-Driven Win-for-All

(AWA)-Hypothesis

82

85

89

90

References

93

About the Author

103

Index 
An earlier version of this research was published in Spanish by Casa Africa/Los Libros de la Catarata, Madrid, Spain, as La Globalizacion de las Inversiones en Africa in 2011: the current version is longer and more updated. 


\section{ACKNOWLEDGEMENTS}

In writing this book, I have benefited from assistance accorded me by many people and institutions.

First and foremost, I would like to express my appreciation to various editors and anonymous reviewers.

This book targets both a general and a specific readership. Generally, it targets readers globally - in Africa, Brazil, China, India, Russia and other parts of the world, including the Asia-Pacific and North and South America regions - as this is a book framed in the literature on globalization that I have researched and taught on from various perspectives during the past 15 years. But it also specifically targets a European readership where I believe I have been frank in suggesting how Europe can reposition itself to effectively compete with emerging players on the African investment scene.

I am grateful to the following scholars for reading all or some parts of this book and offering useful comments and suggestions: Frances Bodomo, Gao Xiaohui, Marcus Schuetz, Che Dewei and Moses Kiggundu. Professor Kiggundu has written a comprehensive forward for this book and is already one of the first readers to have demonstrated a thorough appreciation of the message of the book. I am extremely grateful for his generous comments. I thank students and other sit-in participants in three of my courses on Globalization: African Experiences, Foundations in African Studies and Africa-China Relations, all offered at the University of Hong Kong and at the University of Vienna, for 
countless hours of discussions, many of which relate to the subject matter of this book. I have presented draft chapters of the book at many audiences and I wish to acknowledge the useful feedback that has led to several revisions and reformulations of the book manuscript.

Finally, I am grateful to my research assistants Lucille $\mathrm{Hu}$, Phoebe Li and, particularly, Yuky Liu and Caroline Pajancic who have worked with me over the years to help me to prepare a camera-ready version of the book manuscript. 


\section{FOREWORD}

Professor Adams Bodomo, a native of Ghana, formerly resident of Hong Kong, and now resident of Austria, personifies a gratifying and growing number of globally minded African intellectuals boldly presenting alternative approaches to African development and its dynamic relationships with other parts of the world. In seeking to clarify, redefine and reshape Africa's changing position in the increasingly globalizing world, he, like many of his generation, takes a humanistic, nationalistic and at the same time Pan-Africanist approach, aimed at improving the lives of ordinary Africans, their communities and countries. He rejects traditional Eurocentric approaches and seeks alternatives to maximizing Africa's benefits and minimizing costs from globalization of foreign investment. As a globalized African scholar, Professor Bodomo is uniquely qualified to reframe the discourse about the globalization of Africa, its changing relationships with Europe, China and other emerging economies, seeking a more balanced approach with Africa in the lead.

Like many African Africanists, Professor Bodomo firmly believes that Africa will get maximum benefits for its resources and markets only if it succeeds in evolving an Africa - driven foreign investment policy to regulate all foreign investors on a bilateral basis as opposed to entering into multilateral investment relations. This is a powerful message that he wants all his readers - Europeans, Asians, 
South Americans...or fellow Africans - to internalize. By raising the important question as to whether or not Africa and the Africans can manage globalization to advance their own development, he affirms the strong conviction many of his generation share that indeed globalization can and must be managed for the benefit of all. Once again, we are reminded of the fact that management matters, and that those who have the capacity and tenacity to manage globalization in all its dimensions will survive and even thrive. Those without are likely to suffer and be permanently marginalized.

In this concise book, Professor Bodomo has a message for us all. For Europeans, the message is clear: European investments have not always been beneficial to Africa and the Africans, especially those at the bottom of the pyramid. The European Union needs to change its economic relations with Africa and separate politics from commerce ... in his words 'let politics be politics, and investment be investment'. This is not a new message, but it takes on new urgency because, for the first time, Africa has a growing number of alternative economic partners. Evidently, both Europe and the US governments are deeply concerned about China's deepening economic engagements with Africa. In 2011 alone, then Secretary Clinton accused the Chinese of neocolonialism in eastern and southern Africa, the Germans accused them of being a contributing factor to the famine in eastern Africa and David Cameroon accused them of 'stealing' trade, investment and business opportunities in Nigeria from the UK-based companies. Critics have linked these European anxieties with NATO type military operations in Africa.

On the whole, Europeans find it difficult to change because attitudes towards Africa and the European institutions that deal with Africa have not changed that much since 
colonial times. Europe's ongoing public finance difficulties relating to national budgets, deficits and an uncertain Euro have weakened its capacity and influence to compete for international investment, especially in high-risk environments. European business in Africa is dominated by old conservative oligopolistic companies, and bilateral relations are driven by foreign aid and military, NATO type operations. Most European countries have strong domestic NGO constituencies addicted to foreign aid with little or no interest in promoting trade or investment with Africa. European global growth companies that Professor Bodomo refers to as the future drivers of global business and commerce are hardly present in Africa. Until European business and government leaders can change the way they deal with Africa by replacing conditionalities with conditions, improving the quality of partnerships with Africans, and substantially providing more opportunities for trade and investment rather than focusing almost exclusively on relief and aid, Africans of Professor Bodomo's generation will remain unimpressed, and probably hostile. The challenge is for both Europe and Africa to effectively manage this needed transformational aspect of globalization.

Professor Bodomo has an equally important message for China and the Chinese. Western reactions to China's growing economic engagements with Africa have been lukewarm, controversial and at times hostile, but Professor Bodomo takes a different view. He sees China as a game changer, paradigm shifter, providing alternative and potentially better models for African development, international relations and helping Africa to overcome its global marginalization. China's 'don't ask, don't tell' approach to Africa's internal affairs, its willingness to combine aid with trade and investment, its experience in managing projects in high-risk environments and its strategic and long-term approach to 
relationship building combine to present a positive picture for Africa. Indeed, as an emerging superpower with a strong growing economy, China is well positioned not only to play a leading role in the global economy and global society but also to significantly change the rules of the game governing global institutions. This has profound implications; key among them is the urgent need for Africa and China both to improve their individual and collective capacities to manage Africa-China globalization to mutual advantage.

Under present global conditions, it would appear that there is no country with the potential to do more for African economic development and transformation than China. But for this to happen, both China and Africa must get it and get it right. While China has a strategy for Africa (e.g. FOCAC), Africa is yet to articulate its strategy for China. The challenge, however, is that neither China nor Africa is monolithic. Accordingly, both sides need differentiated and carefully targeted strategies to reflect changing realities in China, Africa and globally. We need to go beyond continental organizations like the African Union, regional organizations like ECOWAS, and seek more operational strategies among complementary countries (e.g. Kenya and South Sudan), sectors (e.g. transport, energy) or development issues (e.g. urbanization). Likewise, Africa needs to do more to attract investments from Chinese investors outside Beijing, and focus on the emerging private sector, provincial governments and town and village enterprises (TVEs). As China continues its domestic economic reforms, these will become the prime drivers of the country's going global policy, foreign investment and globalization.

There are many things China can do to achieve codevelopment with Africa, within the context of a revised FOCAC framework, and on regional and bilateral relations. 
It is important to diversify trade and investment to include sectors other than resource extraction and infrastructure building, and to include African countries not endowed with minerals or petroleum. China needs to open its vast domestic markets to African exports, not only by reducing tariffs, but more importantly, by forming joint ventures with African producers, especially those in the private sector. A key area where China, rather than Europe, can be particularly helpful is the development of an African enterprise private sector, globally competitive and capable of growing African trade and investments. Only by helping Africa to build a strong and globally competitive economy and effective state will China be a true partner and paradigm shifter, different from earlier Europeans. This is the essence of Professor Bodomo's message to the Chinese.

Growing up in East Africa, I remember seeing many people of Indian origin engaged in business, trade and commerce. Indeed, for a number of African countries, the Indian community served as the link with the global economy. However, unlike many of the Chinese people we see in Africa today, the Indians were settlers rather than expatriates. Accordingly, the message Professor Bodomo offers for India - the Indian government and Indian investors in India - is rather different. Indeed, the Indian government and investors have been slow to respond to Africa's growing economic opportunities, in spite of well-established Indian roots in Africa. While India, like China, is an emerging global economic power, India is not China. It is wrong for India to emulate China in Africa, and it is wrong for Africa to deal with India as if it were China. Professor Bodomo's message here is clear: Africa and India need to identify areas of socio-economic complementariness in terms of sectors (e.g. services), institutions (e.g. public administration) and businesses (e.g. business processes) and develop investments of mutual advantage. India also needs to 
work with Africa to help access its growing domestic market for African goods and services and technology both for public administration and productive enterprises. India can also be a game changer and paradigm shifter for African international investment and development, if the global relationships between the two are strategically calibrated and managed.

We now turn to the message that Professor Bodomo offers to African leaders and policy makers. The first message is that with globalization, economic management and public administration become much more difficult and challenging. Not only do leaders and policy makers have to deal with Europeans, but they must also deal with competing and often conflicting expectations from the Chinese, Indians and others from the South. At the same time, the global economy changes so fast that the reasons for foreign investors to come and invest often differ from those for staying and investing more. For example, if the Chinese originally came for oil and minerals, now they are also interested in African land to grow food for their own people, banking to finance trade and investment and deep sea ports to service global supply chains. Governance, leadership and management become equally complex, and require competent, proactive, strategic thinking and operational efficiency both in the public and private sectors. While friendship, trust and a sense of brotherhood are important, especially for South-South international investments, nothing replaces strategic thinking and business acumen. I see Professor Bodomo's message as a challenge for African leaders and policy makers to make sure that they have the individual, institutional and national capacities and competencies to effectively manage the complexities of globalization to mutual advantage. Failure to do so would mean that it does not matter whether it is the Europeans, the 
Chinese or the Indians; Africa would not benefit from foreign investment, not matter where it comes from.

Finally, as an academic, Professor Bodomo has a message for the academic community. His first message is that all his propositions and hypotheses are subject to empirical verification. We must not take his word for gospel truth. Rather, we must apply rigorous research to test whether or not his work can be supported by independent evidence. For example, there is a need for longitudinal and comparative studies of European, Chinese and Indian investments in Africa to determine if indeed there are significant differences, over a period of time, among them in terms of net benefits to Africa and the Africans. As well, Professor Bodomo's bold assertions that China's economic engagements with Africa constitute a paradigm shift which has also reduced the continent's global marginalization need further discussion and research. The alternative view is that China's contributions to Africa' economies are additive and transactional, rather than transformational, and that Africa still remains marginalized in terms of global economic, political and international relations. African NGOs seem to have taken a lead from their European cousins and condemned Chinese engagements with Africa. Professor Bodomo is challenging them to think again, or at the very least to suspend judgement until more objective evidence is available.

Taking a page from recent Chinese economic development, Professor Bodomo seems to draw comparisons between the role played by ethnic Chinese and the African Diaspora in the development of their respective economies. Here again, we need both experience based (case studies) and empirical research to establish the role of the African Diaspora in advancing African globalization and international foreign investment. If management is important for globalization, then we need management research and development to 
ensure a level playing field for Africa. Since most African states are dominated by an overreaching state and a relatively small or weak business sector, we also need research that informs of the optimal institutions and institutional arrangements needed to support the effective management of African globalization and foreign trade and investment. There is also the question of comparing and testing for the salience and applicability of Sino-capitalism (market economy with Chinese characters) with Western type of capitalism for the varied emerging African economic systems. There is much Africa can learn from China in terms of proper pacing and sequencing of economic reforms.

Admittedly, not everyone will agree with everything Professor Bodomo has said. For example, he may have underestimated the positives of European investments in Africa, too upbeat about China and unduly optimistic about Africa's capacity and tenacity to manage globalization to advantage for all. His failure to clearly differentiate, in this book, between official China (bilateral or multilateral) and the growing highly differentiated Chinese participants from the private sector (individuals, SMEs), and even provinces (e.g. TVEs) in Africa or the many Africans who live and work in China does not take into account the more recent changes in Africa-China relations. Yet, we all agree that the questions he has raised and the intellectual rigour with which he has treated the salient issues remain important and laudable. The messages embedded in this work are not only relevant for Africa's former colonial masters but also for China, India and present and future members of the evolving GEEP (group of emerging economic powers). As Professor Bodomo has promised, this short exposé should be seen as the first of a series of publications that will critically examine globalization of foreign investment in Africa with different global 
players. We look forward to reading this and other works by Professor Bodomo.

Moses Kiggundu

Professor,

Management and International Business, Sprott School of Business,

Carleton University, www://sprott.carleton.ca

Note: Professor Kiggundu is also currently editor of the African Journal of Management (AJOM). He is also a member of the African Capacity Building Foundation (ACFB). 